\title{
Protective role of Mannose binding Lectin (MBL2) promoter haplotypes on TB infection in South Indian HIV-1 patients
}

\author{
Kalaimani Pandian', Stalinraja Maruthamuthu', Suresh Madasamy², Jayalakshmi Mariakuttikan ${ }^{1 *}$ \\ From 2nd International Science Symposium on HIV and Infectious Diseases (HIV SCIENCE 2014) \\ Chennai, India. 30 January - 1 February 2014
}

\section{Background}

Mannose binding Lectin (MBL) mediates protection against infections by activating the complement system, but certain microorganisms may increase infectivity by exploiting this host defence system. Hence, the purpose of this study is to evaluate MBL genetic variants with the development of TB infection caused by Mycobacterium tuberculosis among HIV patients.

\section{Methods}

Blood samples from TB+ART + and $\mathrm{TB}^{-} \mathrm{ART}+(\mathrm{n}=30)$ were collected. Genomic DNA was extracted from Peripheral Blood Mononuclear Cells (PBMC) using salting out procedure. MBL promoter haplotypes of $-550 \mathrm{H} / \mathrm{L}$ and $-221 \mathrm{Y} / \mathrm{X}$ associated with high, medium and low (HY, LY and LX) secretion was assessed by PCR-SSP.

\section{Results}

The Promoter haplotype (LY/LX) associated with deficient MBL levels conferred a protective role to TB in our study population with a significant difference (Chi-square $\left.\left(X^{2}\right)=4.00 ; \mathrm{p}<0.05\right)$.

\section{Conclusion}

In this study, we could observe MBL2 promoter haplotypes with low MBL secretion may play a protective role to intracellular mycobacterium infections like TB in HIV seropositive individuals.

\footnotetext{
* Correspondence: jayalakshmim@genomicsmku.org

'Department of Immunology, School of Biological Sciences, Madurai Kamaraj University, Madurai- 625021, India

Full list of author information is available at the end of the article
}

\section{Authors' details}

'Department of Immunology, School of Biological Sciences, Madurai Kamaraj University, Madurai- 625021, India. ${ }^{2}$ ART Centre, Govt. Theni Medical College and Hospital, Theni- 625512, India.

Published: 27 May 2014

doi:10.1186/1471-2334-14-S3-P37

Cite this article as: Pandian et al:: Protective role of Mannose binding

Lectin (MBL2) promoter haplotypes on TB infection in South Indian HIV-1 patients. BMC Infectious Diseases 2014 14(Suppl 3):P37.
Submit your next manuscript to BioMed Central and take full advantage of:

- Convenient online submission

- Thorough peer review

- No space constraints or color figure charges

- Immediate publication on acceptance

- Inclusion in PubMed, CAS, Scopus and Google Scholar

- Research which is freely available for redistribution
() Biomed Central 